Daniel Irving in the Virus House (the pioneering study of Walker's subject), made clear how great a blow to their selfimage was the discovery that the Allies had accomplished what they had not come close to achieving. Hahn accused the others of being second rate; they had no stock in trade; they had not done outstanding science; they had suffered a defeat as inglorious as the Luftwaffe's. Immediately on recovery from the shock of Hiroshima, the scientists began to fashion what Walker calls "the myth of the German atomic bomb". Heisenberg was the leading mythologist. In a stream of apologia, he claimed that the German project had been conducted as pure science, that the scientists had been in charge all along, that they would never have made a bomb for Hitler, that only a very few scientists were "political" - that is, worked to secure the goals of the Nazi regime - and that the leaders of the project conducted their research according to the norms of apolitical science.

The apologia irritated scientists in the Allied countries, especially emigrés, but it worked well enough with military government that Heisenberg became a respected character witness on behalf of scientists undergoing denazification. He even put in a good word for Johannes Stark, one of the fountainheads of Deutsche Physik, an anti-Semitic, anti-modern movement directed against Einstein and "white Jews", like Heisenberg, who taught theoretical physics in the Jewish style. Walker makes the penetrating observation that for Heisenberg and the other nuclear scientists, it was not necessary to brand their former enemies in Deutsche Physik as Nazis, only as poor physicists who had used the apparatus of the state to obtain positions they did not deserve. That allowed the useful line-up of the competent and apolitical against the incompetent and political.

Walker permits his protagonists to hide behind his conception of their conception of professional scientific behaviour. $\mathrm{He}$ gives the case of Harteck, who tried to persuade Norwegian scientists to cooperate in increasing the supply of heavy water, which, he said, would be used only for basic research. Walker finds "no reason to doubt his sincerity", but allows that the minefields, barbed wire and SS men surrounding Norsk Hydro might have made the Norwegians question it. Then there is Heisenberg, travelling up and down the occupied territories as an ambassador of German culture, justifying the ruthlessness of German administration as the lesser of two evils, the other being democracy. Later Heisenberg claimed that his behaviour amounted to active opposition to the regime. This is almost too much for Walker. "[It] is very difficult to reconcile with his actions." Yet Walker writes that in making his claim
Heisenberg was "sincere." Again, Heisenberg tried to give the impression that the German project did not proceed as quickly as it could have because he and his circle held back for moral reasons. Walker says that "Heisenberg's article should be taken as what it was, an honest sincere account of his retrospective misgivings. ... However, this article presented an inaccurate account of [his] actions." Double-think is contagious.

On the apolitical or professional level, Walker has constructed a very good book. He has studied captured documents, gov-

ernment and military reports, and archival material, and integrated the results with interviews he has conducted with veterans of the uranium project. The integration, which presents the story of the project against the changing fortunes of the war, is easy to follow. It provides the facts in sufficient detail and context to permit readers to construct their own solutions to whatever moral or ethical questions they may think it raises.

J. L. Heilbron is in the Office for History of Science and Technology, University of California, Berkeley, California 94720, USA.

\section{Fact and fantasy}

\section{Jeffrey A. McNeely}

Tom Slick and the Search for the Yeti. By Loren Coleman. Faber and Faber: 1989. Pp. 176. Pbk \$11.95.

As human influences reach further into the world's shrinking wildernesses, people continue to be fascinated by the possible existence of unknown animals. Each Himalayan climbing season brings new

\section{IMAGE UNAVAILABLE FOR COPYRIGHT REASONS}

The American Big Foot - who needs further proof? sightings of tracks or other evidence of the Yeti, the famous man-like creature said to haunt the snowy peaks along the NepalTibet border.

One of the strongest supporters of a systematic approach to cryptozoology, the study of animals which have not yet been proved to exist, was Tom Slick. No flyby-night publicity seeker, Slick made millions from oil and real-estate and was the founder of the Southwest Research Institute, one of the largest nonprofit applied research institutes in the world (behind only the Batelle Memorial Institute and the Stanford Research Institute). Despite the inherent public appeal of cryptozoology, Slick avoided publicity, which is attributed in this book to his step-father's kidnapping in the 1930s by the infamous American gangster "Machine Gun" Kelly. Slick's death in a mysterious aeroplane crash (some claiming a link to power struggles over the \$140-million budget of the Southwest Research Institute) at the age of 46 in 1962 spelled the end of significant funding for cryptozoology.

Although Slick was sympathetic to the idea of unknown animals, he also sought proof before claiming that such creatures actually existed. Loren Coleman has no such concerns, stating unequivocally that Yetis do exist but not backing up this assertion with any new evidence. His short book contains 134 pages, 20 of them directly reprinted from one of the classics of cryptozoology, On the Track of Unknown Animals, by Bernard Heuvelmans (Hart-Davis, London, 1958). The information provided by several expeditions into northeastern Nepal in the late 1950 s reveals more about the searchers than the Yeti. Members of the 1959 Slick expedition stole the thumb and phalanx of a mummified hand held at the lamasery of Pangboche, which was claimed by the Sherpas to be a hand of a Yeti. Slick's minions substituted the thumb and phalanx from a human skeleton, thereby throwing into confusion all subsequent investigation of the Pangboche hand. The relics were taken to India, where they were smuggled to London by none other than the film actor James Stewart, an old friend of Slick. Although the insights into Tom Slick and his cryptozoology expeditions are intriguing, they shed no new light on the Yeti itself, which continues to occupy the remote wildernesses of the human spirit.

Jeffrey A. McNeely is at the International Union for Conservation of Nature and Natural Resources (IUCN), 1196 Gland, Switzerland. 